\title{
HSCT FOR CHRONIC MYELOPROLIFERATIVE DISEASES
}

\author{
Vaneuza Araújo Moreira Funke'; Marcos Paulo Colella²; Antonio Vaz de Macedo³; Gustavo Machado \\ Teixeira ${ }^{4}$; Andreza Alice Feitosa Ribeiro ${ }^{5}$; Afonso Celso Vigorito ${ }^{6}$
}

1 Adult Bone Marrow Transplant Unit Coordinator, Hospital de Clínicas, Federal University of Paraná (UFPR); Assistant Professor of Hematology, UFPR; Master's Degree in Hematology, UFPR, PR, Brazil; Fellow at the Long Term Follow Up Division - Seattle- Washington, USA.

2 Hematopoietic Stem Cell Transplant Unit Member, HEMOCENTRO /UNICAMP; Master's Degree in Internal Medicine, School of Medicine, UNICAMP, SP, Brazil.

3 Hematology Clinic Coordinator, Hospital da Polícia Militar, MG; Bone Marrow Transplant Unit Member, Hospital Luxemburgo, Instituto Mário Penna, MG; Teaching Assistant, PPCR/ECPE, Harvard T.H. Chan School of Public Health, USA; Master's Degree in Health Sciences: Infectious Diseases and Tropical Medicine, School of Medicine, Federal University of Minas Gerais (UFMG), MG, Brazil.

4 Bone Marrow Transplant Unit Coordinator, Hospital das Clínicas, UFMG; Hematologist, Hospital Alberto Cavalcanti, FHEMIG, MG; Master's Degree in Sciences Applied to Adult Health Care, School of Medicine, UFMG, MG, Brazil.

5 Bone Marrow Transplant Unit Member, Hospital Israelita Albert Einstein, SP, and Instituto Nacional de Câncer, RJ; Bone Marrow Transplant Unit Coordinator, Hospital Maternidade Brasil, SP; PhD in Health Sciences, USP, SP, Brazil.

6 Bone Marrow Transplant Inpatient Unit Coordinator, UNICAMP; PhD in Internal Medicine, UNICAMP, SP, Brazil; Post-Doctoral Researcher, Seattle- Washington, USA.

\section{INTRODUCTION}

According to the World Health Organization, myeloproliferative neoplasms (MPN) are defined as clonal diseases caused by proliferating hematopoietic progenitor cells. They can be divided into Philadelphia-positive - chronic myeloid leukemia (CML) - and Philadelphia-negative disorders - primary myelofibrosis (PMF), polycythemia vera (PV), and essential thrombocythemia (ET). ${ }^{[1]}$ This document is a summary of the recommendations of the Brazilian Society of Bone Marrow Transplantation Consensus Panel in 2020 for these areas.

\section{PHILADELPHIA-POSITIVE MYELOPROLIFERATIVE DISEASE}

\section{CHRONIC MYELOID LEUKEMIA: SUMMARY OF RECOMMENDATIONS}

1. Imatinib mesylate, nilotinib, or dasatinib are the treatment of choice for newly diagnosed chronic phase (CP) chronic myeloid leukemia (CML) (level 1b). ${ }^{[2-9]}$

2. Main indications for hematopoietic stem cell transplantation (HSCT) for CML patients in the tyrosine kinase inhibitor (TKI) era:

a. Children: there are no currently available stud- ies comparing TKI and HSCT in this population. The therapeutic approach is similar to that in adults and is based on the use of first or second generation TKIs. Hematopoietic Stem Cell Transplantation (HSCT) should be considered after failure of a second generation TKI or in advanced phase (AP and BC) CML. Data on the primary efficacy and safety of ponatinib are still lacking in children, for which further studies are awaited. Likewise, ongoing studies are still assessing the adverse effects of the long-term use of TKIs in this population. Adherence to TKI therapy should also be taken into account when deciding upon the best treatment

strategy in children and adolescents (level 2b). ${ }^{[10-15]}$

b. Advanced phase disease: in AP, HSCT should be indicated if the response to second generation TKI therapy (dasatinib or nilotinib) is suboptimal, or in case of a T315I mutation when ponatinib is unavailable. ${ }^{[16-20]}$ In BC, it should always be considered, preferably after a preliminary course of TKI therapy with or without chemotherapy (level 2b). ${ }^{[21,22]}$

c. In case of failure of imatinib, in accordance with the European LeukemiaNet 2020 recently updated criteria, in the absence of a T315I mutation, a second generation TKI should be started. In case of TKI failure, consider third generation TKI therapy (ponatinib) or HSCT, if the former is unavailable (level $2 b$ ). 
d. T315I mutation, if ponatinib is unavailable (level 2b). ${ }^{[18,19]}$

3. For young patients with an HLA-identical related or unrelated donor, myeloablative conditioning should be used. Reduced intensity or non-myeloablative conditioning should be reserved for patients over 60 years of age and/or with significant comorbidities (level 1b). ${ }^{[24-27]}$

4. Graft-versus-host disease (GVHD) prophylaxis should be based on a calcineurin inhibitor (cyclosporin, tacrolimus) plus methotrexate. In a long-term follow-up analysis, triple immunosuppressant-based prophylaxis with methylprednisolone resulted in better overall survival, but these results are yet to be confirmed in larger, prospective studies (level 1b). $[28,29]$

5. Bone marrow, if available, is the preferred stem cell source in patients with CP CML. Patients with advanced disease should receive peripheral blood stem cells (PBSC). Alternative stem cell sources, such as umbilical blood cord (UBC), or haploidentical transplants are acceptable in the absence of an HLA-identical BM (or PBSC) donor (level 1a). ${ }^{[30-33]}$

6. Post-transplant monitoring of $B C R-A B L$ using real time quantitative polymerase chain reaction (RT-qP$\mathrm{CR}$ ) should be performed every three months, during the first two years, and every six months, up to five years post-transplant. This should be followed by yearly monitoring from then onwards (level $2 b$ ). ${ }^{[34-37]}$

7. Molecular relapse is defined as progressively increasing $B C R-A B L / A B L 1$ gene transcripts in at least two consecutive results (level 2b). ${ }^{[36,37]}$

8. Use of imatinib mesylate and of second generation TKIs (dasatinib and nilotinib) does not seem to affect the occurrence of early transplant-related toxicity, nor to delay engraftment. Similarly, it does not seem to affect survival, relapse, or non- relapse mortality (level 2b). ${ }^{[38-40]}$

9. In case of molecular relapse, consider donor lymphocyte infusions (DLI) at escalated doses $(1 \times 106$, $5 \times 106,1 \times 107,5 \times 107,1 \times 108$ CD3+ cells $/ \mathrm{kg}$ ) at three-month intervals. In case of cytogenetic or hematologic relapse, consider DLI at escalated doses at three-month intervals, starting at $1 \times 107$ CD3+ cells $/ \mathrm{kg}$, or consider use of imatinib mesylate. Subsequent DLI doses should not be administered if a satisfactory response is obtained or in case chronic GVHD ensues. In case of unrelated or haploidentical related donors, start at a DLI dose 1 log lower than that depicted above (1b). In case of hematologic relapse in $\mathrm{CP}$ or cytogenetic relapse, consider DLI, starting at higher escalated doses $(1 \times 107,5 \times 10$ $7,1 \times 108 \mathrm{CD} 3+$ cells $/ \mathrm{kg}$ ), or imatinib mesylate, at a dose of $400 \mathrm{mg}$ per day, or a combination of these. In case of hematologic relapse in AP or BC, consider the use of a TKI plus DLI (level 1b). ${ }^{[41-46]}$

10. Imatinib mesylate, nilotinib, or dasatinib are currently acceptable alternatives to DLI for the treatment of post-transplant relapse of $\mathrm{CML}$, or in cases where relapse occurs in the setting of chronic GVHD (level 2b). TKIs may also be combined with DLI in the management of such cases, with better overall responses (level 2b). Prompt and long-lasting responses are usually seen under TKI therapy for CML relapsing in $\mathrm{CP}$ (level 2b). Response tends to be worse and less durable in AP or BC relapse (level 2b). ${ }^{[47,48]}$

11. In patients previously resistant or intolerant to imatinib mesylate, consider using a second generation TKI (nilotinib or dasatinib), when deciding upon use of a TKI alone or in combination with DLI (level $2 b)$. In patients previously resistant or intolerant to more than one TKI, consider using a previously unused TKI, or opt for DLI without a TKI, in the absence of chronic GVHD (level 2b). ${ }^{[47,48]}$

12. Consider using post-transplant TKI prophylaxis in patients at a high risk for relapse ( $>1$ st CP and AP/ BC) (level 2b). ${ }^{[49-53]}$

13. In case a post-transplant $B C R-A B L$ fusion gene mutation is detected, the mutational profile should be taken into account when choosing the most appropriate TKI for prophylaxis or preemptive therapy in this setting (level 2b). ${ }^{[54 \mid}$

14. A second allogeneic HSCT may be considered in case of TKI- and/or DLI- resistant relapse following a first transplant, if a suitable donor is available, in the absence of contraindications to transplant (level 2b). [55] 
TABLE 1- Response to TKI definitions. ${ }^{31}$

\begin{tabular}{|c|c|c|c|}
\hline Time & Optimal Response & Failure & Warning \\
\hline Diagnosis & - & - & $\begin{array}{c}\text { High risk (ELTS) } \\
\text { additional clonal abnormalities in } \mathrm{Ph}+ \\
\text { cells (ACA) }\end{array}$ \\
\hline 3 months & RTQPCR (EI) $\leq 10 \%$ & $\begin{array}{l}>10 \% \text {, confirmed in- } 3 \\
\text { months }\end{array}$ & $R Q P C R>10 \%$ \\
\hline 6 months & RTQPCR (El) $\leq 1 \%$ & RQPCR $>10 \%$ & RQPCR 1 a $10 \%$ \\
\hline 12 months & RTQPCR(EI) $\leq 0,1 \%$ & $\mathrm{RQPCR}>1 \%$ & RQPCR 0,1 a $1 \%$ \\
\hline Any moment & $\begin{array}{l}\text { MMR sustained RTQPCR } \\
(\text { EI) } \leq 0,1 \%\end{array}$ & $\begin{array}{l}\text { RQPCR }>1 \% \text {, resistant } \\
\text { mutation, additional } \\
\text { clonal abnormalities in } \\
\text { Ph+ cells }(A C A)^{* *}\end{array}$ & RQPCR 0,1 a $1 \%$; loss of MMR \\
\hline
\end{tabular}

* ELTS: EUTOS long term survival score

Adapted from: Hochaus, A, et al. Leukemia 2020;34(4):966-984 ${ }^{23}$.

** Two results exhibiting the same abnormality in at least two $\mathrm{Ph}+$ cells are necessary to fulfill this criterion: TKI: tyrosine kinase inhibitor; MMR: major molecular response; ACA: additional chromosome abnormalities in Ph+ cells; RTPCR: real-time quantitative polymerase chain reaction; IS: International Scale (BCR-ABL/ABL1 control gene ratio).

*** Risk scores can be calculated directly by accessing the following site: http:/leukemia-et.org/content/leukemias/cml/cml_score/index_eng.html.

TABLE 2 - European LeukemiaNet 2020 chronic myeloid leukemia treatment recommendations31

\begin{tabular}{|c|c|}
\hline $\begin{array}{c}\text { Prevention by elimination of BCR-ABL1 } \\
\text { Early: emergence of high-risk ACA }\end{array}$ & $\begin{array}{c}\text { Assurance of effective TKI treatment } \\
\text { Observe closely, consider intensification of treatment (ponatinib, } \\
\text { early allo-SCT) }\end{array}$ \\
\hline Resistance to second generation TKI & $\begin{array}{c}\text { Start with imatinib, change to a 2nd generation TKI according to } \\
\text { mutation profile }\end{array}$ \\
\hline Ponatinib failure & $\begin{array}{r}\text { Ponatinib or clinical trial, consider HSCT, donor search } \\
\text { High risk of progression, early allo-HSCT recommended }\end{array}$ \\
\hline Progression to blast phase & $\begin{array}{r}\text { Treat as high-risk patients; proceed to allo- HSCT if response to TKI is } \\
\text { not optimal. }\end{array}$ \\
\hline $\begin{array}{r}\text { Poor outcome with currently available TKIs. } \\
\text { Add chemotherapy based on AML regimens for myeloid BC (such as } \\
\text { dasatinib or ponatinib + FLAG-IDA) or ALL regimens for lymphoid } \\
\text { BCP (such as imatinib or dasatinib + hyperCVAD). } \\
\text { Choice of TKI based on prior therapy and mutational status. } \\
\text { Proceed to allo-HSCT soon after CP2 is achieved }\end{array}$
\end{tabular}

Adapted from: Hochaus, A, et al. Leukemia 2020;34(4):966-984 22.

TKI: tyrosine kinase inhibitor; ACA: additional chromosomal aberrations: 2CP: second chronic phase; BC: blast crisis; allo- HSCT: allogeneic hematopoietic stem cell transplant; AML: acute myeloid leukemia; ALL: acute lymphoblastic leukemia; FLAG-IDA: fludarabin + cytarabin + granulocyte-colony stimulating factor + idarubicin; HiperCVAD: hyperfractionated CVAD: cyclophosphamide + vincristin + doxorubicin + dexamethasone.

Figure 1: Treatment algorithm for chronic phase (CP), accelerated phase (AP), and blasts crisis (BC) chronic myeloid leukemia (CML). 31 
FIGURE 1 - Treatment algorithm for chronic phase (CP), accelerated phase (AP), and blasts crisis (BC) chronic myeloid leukemia (CML).31
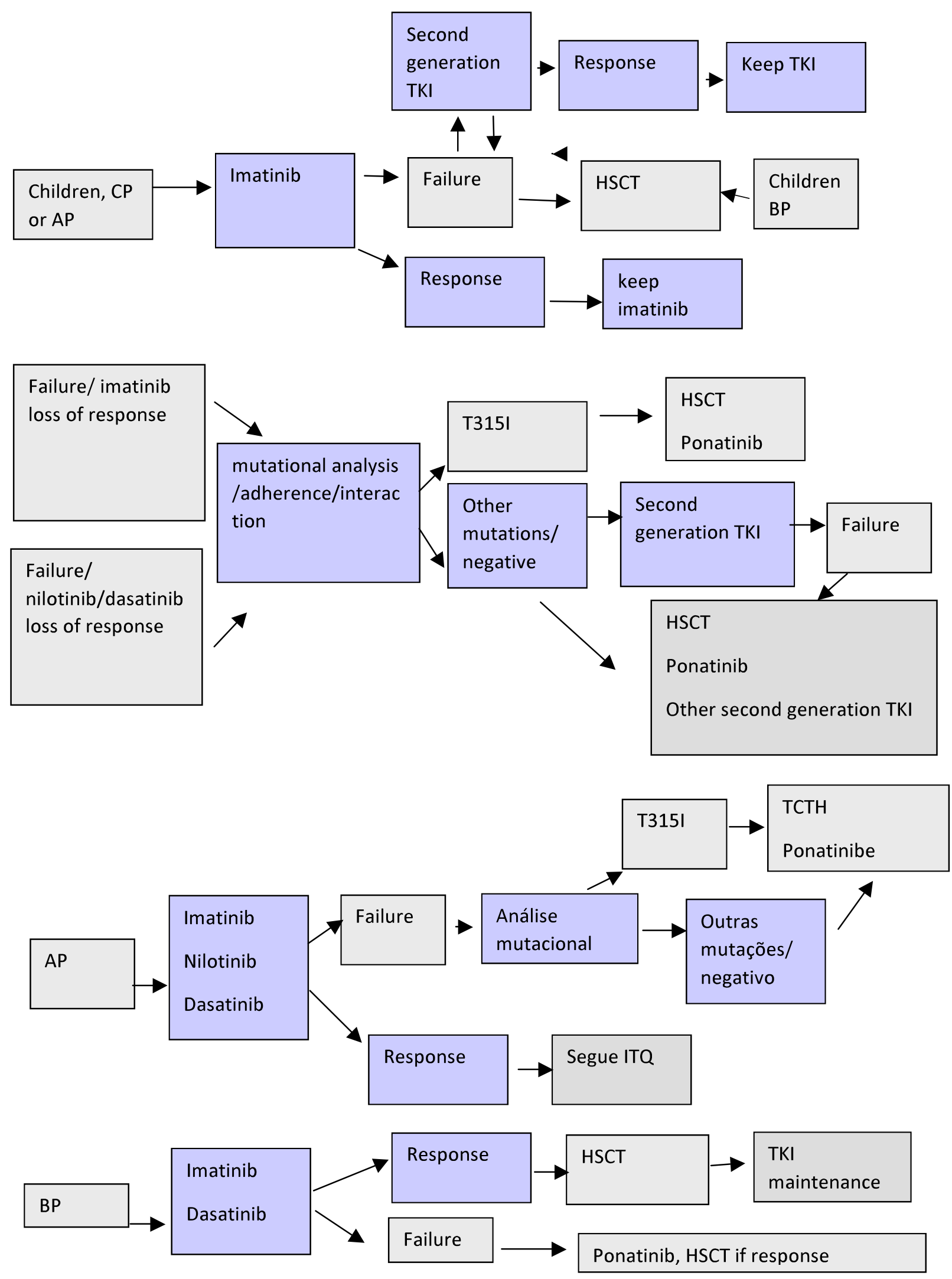
TABLE 3 - Recommendations for post HSCT monitoring and relapse therapy in CML patients 41-46

\begin{tabular}{|c|c|c|c|}
\hline Time after HSCT & MONITORIZATION & RESULT & INTERVENTION \\
\hline Two years & $\begin{array}{c}\text { Quantitative RT-PCR every } 3 \text { months } \\
\text { (level } 2 \mathrm{~b} \text { ) }\end{array}$ & \multirow[b]{3}{*}{$\begin{array}{l}\text { Molecular relapse: } \\
\text { increasing } B C R-A B L / A B L \\
\text { ratio in two measures: } \\
\text { relapse cutoff defined by } \\
\text { local lab (2B) }\end{array}$} & \multirow[b]{3}{*}{$\begin{array}{c}\text { Consider escalated dose DLI. For } \\
\text { related transplants: CD3+/Kg: } 10 \\
6^{\circledR} 5 \times 106^{\oplus} 107^{\circledR} 5 \times 107^{\oplus} 108 \\
\text { every } 3 \text { months. For unrelated } \\
\text { transplants: } 1 \text { log less: } \\
105^{\circledR} 5 \times 105^{\circledR} 106^{\circledR} 5 \times 106^{\circledR} \\
107 \\
\text { Hold dose if chronic GVHD signs } \\
\text { or symptoms (1B) }\end{array}$} \\
\hline 3-5 years & $\begin{array}{c}\text { Quantitative RT-PCR every } 6 \text { months } \\
\text { (level } 2 \text { b) }\end{array}$ & & \\
\hline After 5 years & $\begin{array}{c}\text { Quantitative RT-PCR every year } \\
\text { (level } 2 \mathrm{~b})\end{array}$ & & \\
\hline Any time & $\begin{array}{c}\text { Cytogenetics if positive PCR (level } \\
\text { 2b) }\end{array}$ & Cytogenetic relapse & $\begin{array}{l}\text { Consider DLI as above (1B) and } \\
\text { imatinib (2B) }\end{array}$ \\
\hline Any time & Complete Blood Count & Hematologic relapse & $\begin{array}{l}\text { Consider DLI as above (1B) and } \\
\text { imatinib (2B) }\end{array}$ \\
\hline
\end{tabular}

$\mathrm{DLI}=$ donor lymphocyte infusions; $\mathrm{RT}-\mathrm{PCR}=$ real time polymerase chain reaction 


\section{PRIMARY MYELOFIBROSIS, POLYCYTHEMIA VERA, ESSENTIAL THROMBOCYTHEMIA}

\section{INTRODUCTION}

According to the World Health Organization, myeloproliferative neoplasms (MPN) are defined as clonal diseases caused by proliferating hematopoietic progenitor cells and most common Philadelphia-negative disorders are primary myelofibrosis (PMF), polycythemia vera (PV), and essential thrombocythemia (ET). [1]

\section{STRATIFICATION}

Patients with PMF often have a dismal prognosis, with a mean overall survival of only 6 years after diagnosis. 56 Even so, the clinical course is highly heterogeneous, and survival may vary from a few months to more than 10 years. 57 Therefore, prognosis may be better estimated by a number of scoring systems, among which the Dynamic International Prognostic Scoring System plus (DIPSS plus)58 is one of the most commonly applied. According to this prognostic model, patients stratified as low risk present a median survival of 185 months, which decreases to 78 months in intermediate 1-risk patients, 35 months in the intermediate 2 subgroup, and 16 months in the high-risk category.58 Polycythemia vera and essential thrombocythemia, in turn, have a more favorable prognosis, and patients should only be referred for allogeneic HSCT in case myelofibrosis or leukemic transformation has developed (level 2b).

\section{MUTATIONS}

Mutational profiling, including CALR, MPL, JAK2, ASXL1, EXH2, SRSF2, IDH1/2 and U2AF1 mutations, should be performed whenever possible, to allow for the Mutation Enhanced International Prognostic Scoring System 70+ v2.0 (MIPSS70+ v2.0) 59 and the Clinical-Molecular Myelofibrosis Transplant Scoring System (MTSS) 60 to be applied, given their ability to estimate post-transplant outcomes based on disease-, patient-, and transplant-related factors. This may aid in the clinical decision-making process when assessing eligibility for transplantation. Such prognostic models should not, however, replace the DIPSS plus score when assessing these patients (level 2b).

\section{INDICATION}

No therapeutic agents have thus far been shown to improve the overall survival of patients with PMF; allogeneic HSCT remains the only curative option for such patients to date. Not all patients, however, benefit from this procedure. Hence, we recommend that transplant indication be based on the DIPPS plus score, whereby allogeneic HSCT should be performed in intermediate-2 and high- risk patients.61 HSCT may sometimes be indicated for patients classified as intemediate-1 risk 62 , particularly in younger patients and those with high transfusion dependency, more than $2 \%$ blasts in peripheral blood, or with an unfavorable karyotype. Other scoring systems, namely the MIPSS70+ v2.0 and the MTSS, may further assist in the clinical decision-making process (level 2b).

\section{CONDITIONING REGIMEN INTENSITY}

It is not defined what is the ideal conditioning regimen in transplantation for myelofibrosis patients, given the patients' average age of diagnosis, most regimens will be of reduced intensity, however the ideal dose is not established. For patients under the age of 50, we recommend myeloablative conditioning; for those over 50 years old, reduced intensity conditioning 63, which is usually fludarabine associated with busulfan or melphalan. There is no superiority between conditioning regimens, the melphalan regimen seems to obtain greater control of the disease, but with higher mortality unrelated to relapse than the regimen with busulfan, resulting in similar overall survival 64 .

The MD Anderson group recently published a non-randomized, phase II study comparing 2 different levels of intravenous busulfan associated with fludarabine: 15 patients using low busulfan $(130 \mathrm{mg}$ / $\mathrm{m} 2$ for 2 days) and 31 patients with high busulfan (100mg / m2 for 4 days), with 27 patients with a serum level adjusted to AUC of 4000. In an average follow-up of 3 years, patients using busulfan with a higher dose had an event-free survival of $58 \%$ against $27 \%$ of those who used low doses. In conclu- 
sion, the use of fludarabine regimen with busulfan with serum level control seems to reduce relapse without increasing transplant-related mortality. 65 Non-myeloablative conditions have a higher rate of grafting failure 66 (level 2b).

\section{DONOR}

HLA-matched unrelated donors are an acceptable alternative for patients without an HLA-identical sibling donor. 67 HLA-mismatched related donors may also be acceptable, but further studies are needed to better address this issue (level 2b). [68]

\section{STEM CELL SOURCE}

Both BM and PBSCs are acceptable stem cell sources in this scenario (level 2b).[69]

\section{SPLENECTOMY}

Routine splenectomy prior to transplant is not recommended in patients with splenomegaly, except in cases with a spleen size greater than $22 \mathrm{~cm} 70$. Splenic radiation, in turn, may be considered within the context of clinical trials (level 2b).

\section{RUXOLITINIB}

Ruxolutinib is a Janus kinase (JAK) $1 / 2$ inhibitor known to be involved in the pathophysiology of PMF. Despite its effectiveness in controlling many of the symptoms presented by PMF patients, it should not be regarded as an alternative to HSCT, since it does not affect the natural history of the disease. Hence, though we do recommend it for symptomatic control, it should not delay referral for transplantation.

The use of ruxolitinib in most patients with myelofibrosis (MF) results in a reduction in the size of the spleen, which could decrease the time of grafting in the transplant, in improving constitutional symptoms and therefore in performance status, which could result in improvement of survival, and given the immunomodulatory action on $\mathrm{T}$ lymphocytes, it could decrease the incidence and severity of graft disease against the host. There are some concerns regarding the use of ruxolitinib in pre-transplantation: cytopenias, increased incidence of viral infections such as CMV, increased immunosuppression could interfere with the graft versus disease effect, the withdrawal syndrome: fever, recurrence of symptoms, splenomegaly of rebound, cytokine release syndrome, the latter being more common when the interruption is made abruptly and / or long before the conditioning regime starts.
A prospective study that studied the use of ruxolitinib for 56 days, started 60 days before conditioning, gradually decreased in 4 days and interruption 1 day before conditioning, showed that its use was safe. However, in this group of 21 patients, no significant reduction was seen in the rate of graft failure or in the incidence of GVHD 71. Another prospective study, phase II, this one using ruxolitinib for at least 8 weeks, with a gradual reduction of $5 \mathrm{mg}$ every 4 days and interruption 4 days before the infusion also showed that the use of pre-HSCT ruxolitinib is safe: none patient had cytokine release syndrome and the overall 2-year survival was $86 \%$, suggesting a benefit in overall survival 72 . Level of evidence $2 \mathrm{~b}$. In addition studies have shown that ruxolitinib use is well tolerated during conditioning and others investigate its use in low doses until grafting: in a study with a small number of patients maintained low dose ruxolitinib until $D+28: 2$ out of 12 patients had to cease on medication, the average grafting time was 12 days, no grafting failure, low incidence of acute GVHD and about $40 \%$ reactivation of CMV. [73]

We recommend it be used at the highest tolerated dose, with gradual tapering every four days and complete withdrawal by one to two days prior to transplant. 70 According to a recent phase II study published this year, its use prior to HSCT seems to be safe and to improve overall survival in patients who are referred for transplantation (level 2b) [71]

\section{HAPLOIDENTICAL TRANSPLANTATION IN MYELOFIBROSIS}

The results of haploidentical transplantation in myelofibrosis still lack published data. One of the first reports was published in 2016 analyzing the use of alternative donors from 2000 to 2014, unrelated and haploidentical, with related donors compatible in myelofibrosis 74. Although it was an analysis of a few patients: 23 haploidentical transplants, without which 20 in the last 5 years, the study showed a significant improvement in the survival of transplanted patients with myelofibrosis who used alternative donors: when analyzed the period of 2011 to 2014 the transplant survival curve with compatible related donor and haploidentical donors are comparable.

In 2019, the EBMT group published the retrospective report of 56 patients, median age of 57 years 75 . Myeloablative conditioning was chosen in $70 \%$ of the cases and $59 \%$ of the cases used thiotepa + fludarabine + busulfan with cyclophosphamide in PT; 2/3 used bone marrow as a source of progenitor cells. The grafting rate was $82 \%$. The cumulative incidence of acute GVHD up to D + 100 was $28 \%$ (grade II-IV) 
and 9\% (grade III / IV) and chronic GVHD in 1 year was $45 \%$. In 2 years, overall survival was $56 \%$, the incidence of relapse $19 \%$ and unrelated mortality $38 \%$. This study showed that haploidentical trans- plantation is feasible, with good rates of grafting and overall survival and relapse not unlike unrelated transplants, however approaches must be instituted to decrease the considerable transplant-related mortality rate.

\section{REFERENCES}

1. Arber DA, Orazi A, Hasserjian R, et al. The 2016 revision to the World Health Organization classification of myeloid neoplasms and acute leukemia. Blood; . 127, n. 20, p. 2391-2405, 2016. doi:10.1182/blood-2016-03-643544

2. O'Brien SG, Guillot F, Larson RA, Gathmann I, Baccarani M, Cervantes F,et al. Imatinib compared with interferon and low-dose cytarabine for newly diagnosed chronic-phase chronic myeloid leukemia.N Engl J Med; v. 348, n. 11, p. 994, 1004, 2003.

3. Hochhaus A, Larson RA, Guilhot F, Radich JP, Branford S, Hughes TP, et al. Long-Term Outcomes of Imatinib Treatment for Chronic Myeloid Leukemia. N Engl J Med; v. 376, n. 10, p. 917-927, 2017. doi: 10.1056/NEJMoa1609324.

4. Hughes TP, Kaeda J, Branford S, et al. “Frequency of major molecular responses to imatinib or interferon alfa plus cytarabine in newly diagnosed chronic myeloid leukemia" New England Journal of Medicine; v. 349, p. 1423- 1432, 2003.

5. Kantarjian H, Shah NP, Hochhaus A, et al. Dasatinib versus imatinib in newly diagnosed chronic-phase chronic myeloid leukemia. N Engl J Med; v. 362, n. 24, p. 2260-70, 2010.

6. Kantarjian HM, Shah NP, Cortes JE, Baccarani M, Agarwal MB et al.Dasatinib or imatinib in newly diagnosed chronic-phase chronic myeloid leukemia: 2-year follow-up from a randomized phase 3 trial (DASISION) Blood; v. 119, n. 5, p. 1123- 1129. 2012.

7. Kantarjian HM, Hochhaus A, Saglio G, De Souza C, Flinn IW, Stenke L et al. Nilotinib versus imatinib for the treatment of patients with newly diagnosed chronic phase, Philadelphia chromosome-positive, chronic myeloid leukaemia: 24-month minimum follow-up of the phase 3 randomised ENESTnd trial. Lancet Oncol; v. 12, n. 9, p. 841-51. 2011.

8. Saglio G, Kim DW, Issaragrisil S, et al. Nilotinib versus imatinib for newly diagnosed chronic myeloid leukemia. N Engl J Med; v. 362, n. 24, p. 2251-9, 2010.

9. Cortes JE, Kim DW, Kantarjian HM,et al. Bosutinib versus imatinib in newly diagnosed chronic-phase chronic myeloid leukemia: results from the BELA trial. J Clin Oncol; 2012.

10. Suttorp M, Schulze P, Glauche I, et al. Frontline imatinib treatment in children and adolescents with chronic myeloid leukemia:results from a phase III trial. Leukemia; v. 32, n.7, p. 1657- 1669, 2018.

11. Millot F, Baruchel A, Guilhot J, et al. Imatinib is effective in children with previously untreatedchronic myelogenous leukemia in earlychronic phase: results of the French national phase IV trial. J Clin Oncol; v. 29, n. 20, p. 2827-2832, 2011.

12. Gore L, Kearns PR, de Martino ML, et al.Dasatinib in pediatric patients with chronic myeloid leukemia in chronic phase: resultsfrom a phase II trial. J Clin Oncol; v. 36, n. 13, p. 1330-1338, 2018.

13. Hijiya N, Maschan A, Rizzari C, et al. Efficacyand safety of nilotinib in pediatric patients with Philadelphia chromosome positive (PH1) chronic myeloid leukemia (CML): results from a phase 2 trial [abstract]. Pediatr Blood Cancer; v. 64 2017(S3). Abstract S22.

14. Samis J, Lee P, Zimmerman D, Arceci RJ,Suttorp $M$, Hijiya N. Recognizing endocrinopathies associated with tyrosine kinase inhibitor therapy in children with chronic myelogenous leukemia. Pediatr Blood Cancer; v. 63, n. 8, p. 1332-1338

15. Mancini J, Simeoni MC, Parola N, et al. Adherence to leukemia maintenance therapy:a comparative study among children, adolescents, and adults. Pediatr Hematol Oncol; v. 29, n. 5, p. 428-439, 2012. 
16. Talpaz M, Silver RT, Druker BJ, Goldman JM, Gambacorti-Passerini C, Guillot F et al. Imatinib induces durable hematologic and cytogenetic responses in patients with accelerated phase chronic myeloid leukemia: results of a phase 2 study. Blood; v. 99, n. 6, p. 1928-37, 2002.

17. Jiang Q, Xu L, Liu D, Liu K, Chen S, Jiang B, et al. Imatinib mesylate versus allogeneic hematopoietic stem cell transplantation for patients with chronic myelogenous leukemia in the accelerated phase. Blood; v. 117, n. 11, p. 3032-3040, 2011.

18. Nicolini FE, Basak GW, Kim DW, Olavarria E, Pinilla-lbarz J, Apperley JF et al. Overall survival with ponatinib versus allogeneic stem cell transplantation in Philadelphia chromosome-positive leukemias with the T315I mutation. Cancer; v. 123, n. 15, p. 2875-2880, 2017.

19. Xu LP, Xu ZL, Zhang XH, Chen H, Chen YH, Han $W$, et al. Allogeneic Stem Cell Transplantation for Patients with T315I BCR-ABL Mutated Chronic Myeloid Leukemia. Biol Blood Marrow Transplant; v. 22, n. 6, p. 1080-1086, 2016.

20. Lübking A, Dreimane A, Sandin F, Isaksson C, Märkevärn $B$, Brune $M$, et.al. Allogeneic stem cell transplantation for chronic myeloid leukemia in the TKI era: population-based data from the Swedish CML registry. Bone Marrow Transplant; v. 54, n. 11, p. 1764-1774, 2019.

21. Sawyers CL, Hochhaus A, Feldman E, Goldman $J M$, Miller CB, Ottmann OG et al. Imatinib induces hematologic and cytogenetic responses in patients with chronic myelogenous leukemia in myeloid blast crisis: results of a phase II study. Blood; v. 99, n. 10, p. 3530-9, 2002.

22. Sasaki H, Mitani S, Kusumoto S, Marumo Y, Asano A, Yoshida T, et.al. Pre- and post-transplant ponatinib for a patient with acute megakaryoblastic blast phase chronic myeloid leukemia with T315I mutation who underwent allogeneic hematopoietic stem cell transplantation. Int $J$ Hematol; v. 110, n. 1, p. 119-123, 2019.

23. A Hochhaus, M Baccarani, R T Silver, C Schiffer, J F Apperley, F Cervantes et. al. European LeukemiaNet 2020 Recommendations for Treating Chronic Myeloid Leukemia. Leukemia; v. 34, n. 4, p. 966-984, 2020.

24. Radich JP, Gooley T, Bensinger W, et al. HLAmatched related hematopoietic cell transplantation for chronic-phase CML using a targeted busulfan and cyclophosphamide preparative regimen. Blood; v. 102, p. 31-35, 2003.

25. Saussele S, Lauseker M, Gratwohl A, Beelen DW, Bunjes $D$, Schwerdtfeger $R$ Allogeneic hematopoietic stem cell transplantation (allo SCT) for chronic myeloid leukemia in the imatinib era: evaluation of its impact within a subgroup of the randomized German CML Study IV. Blood; v. 115, n. 10, p. 1880-5, 2010.

26. Chhabra S, Ahn KW, Hu ZH, Jain S, Assal A, Cerny J,et. al. Myeloablative vs reduced-intensity conditioning allogeneic hematopoietic cell transplantation for chronic myeloid leukemia. Blood Adv; v. 2, n. 21, p. 2922-2936, 2018.

27. Kongtim $\mathrm{P}$, Adekola K, Milton DR, Ramlal R, Jimenez $A$, Chen J,et al. Donor type, in addition to transplantation in chronic phase and myeloablative conditioning, influence transplant survival for patients with advanced chronic myeloid leukemia in the era of tyrosine kinase inhibitors. Leukemia; v. 31, n.7, p. 1654-1657, 2017. doi: 10.1038/leu.2017.118. Epub 2017 Apr 12.

28. Tapani Ruutu, Liisa Volin, Terttu Parkkali, Eeva Juvonen, Erkki Elonen. Cyclosporine, methotrexate, and methylprednisolone compared with cyclosporine and methotrexate for the prevention of graft-versus-host disease in bone marrow transplantation from HLA-identical sibling donor: a prospective randomized study. Blood; v. 96, n. 7, p. 2391-2398, 2000.

29. Tapani Ruutu, MD PhD, Anne Nihtinen, MD PhD, Riitta Niittyvuopio, MD PhD, Eeva Juvonen, MD $\mathrm{PhD}$, Liisa Volin, MD. A randomized study of cyclosporine and methotrexate with or without methylprednisolone for the prevention of graftversus-host disease: Improved long-term survival with triple prophylaxis. Blood; v. 128, n. 22, p. 2242, 2016.

30. Stem Cell Trialists' Collaborative Group "Allogeneic Peripheral Blood Stem-Cell Compared with Bone Marrow Transplantation in the Management of Hematologic Malignancies: An Individual Patient Data Meta-Analysis of Nine Randomized Trials. J Clin Oncol. v. 23, p.5074, 5087, 2005.

31. Alousi A, Wang T, Hemmer MT, Spellman SR, Arora $M$, Couriel DR et. al. Peripheral Blood versus Bone Marrow from Unrelated Donors: Bone Marrow Allografts Have Improved Long-Term Overall and Graft-versus-Host Disease-Free, 
Relapse-Free Survival. Biol Blood Marrow Transplant; v. 25, n. 2, p. 270-278, 2019.

32. Lee SJ, Logan B, Westervelt P, Cutler C, Woolfrey A, Khan SP, et al. Comparison of Patient-Reported Outcomes in 5-Year Survivors Who Received Bone Marrow vs Peripheral Blood Unrelated Donor Transplantation: Long-term Follow-up of a Randomized Clinical Trial. JAMA Oncol; v. 2, n. 12, p. 1583-1589, 2016.

33. Holtick U, Albrecht M, Chemnitz JM, Theurich $\mathrm{S}$, Shimabukuro-Vornhagen A, Skoetz N, et al. Comparison of bone marrow versus peripheral blood allogeneic hematopoietic stem cell transplantation for hematological malignancies in adults - a systematic review and meta-analysis. Crit Rev Oncol Hematol; v. 94, n. 2, p. 179-88, 2015.

34. Kaeda J, O'Shea D, Szydio RM, Olavarria E, et al. Serial measurement of $B C R-A B L$ transcripts in the peripheral blood after allogeneic stem cell transplantation for chronic myeloid leukemia: an attempt to define who may not require therapy. Blood; v. 107, p. 4171-76, 2006.

35. Radich JP, Gooley T, Bryant E, et al. The significance of bcr-abl molecular detection in chronic myeloid leukemia patients "late," 18 months or more after transplantation. Blood; v. 98, p. 1701-1707, 2001.

36. Arpinati M, Tolomelli G, Bochicchio MT, Castagnetti $F$, Amabile $M$, Bandini $G$, et al. Molecular monitoring of $B C R-A B L$ transcripts after allogeneic stem cell transplantation for chronic myeloid leukemia. Biol Blood Marrow Transplant; v. 19, n. 5, p. 735-40, 2013.

37. Craddock CF. We do still transplant CML, don't we? Hematology Am Soc Hematol Educ Program; n. 1, p. 177-184 2018.

38. Oehler VG, Gooley T, Snyder DS, et al. The effects of imatinib mesylate treatment before allogeneic transplantation for chronic myeloid leukemia. Blood; v. 109, p. 2007.

39. Lee SJ, Kukreja M, Wang T, et al. Impact of prior imatinib mesylate on the outcome of hematopoietic cell transplantation for chronic myeloid leukemia. Blood; v. 112, p. 1782-1789, 2008.

40. Jabbour E, Cortes J, Santos FP, et al. Results of allogeneic hematopoietic stem cell transplantation for chronic myelogenous leukemia patients who failed tyrosine kinase inhibitors after de- veloping $B C R-A B L 1$ kinase domain mutations. Blood; v. 117, p 2011.

41. Dazzi F, Szydlo RM, Cross NC, et al. Durability of responses following donor lymphocyte infusions for patients who relapse after allogeneic stem cell transplantation for chronic myeloid leukemia. Blood; v. 96, n. 8, p.2712-2716, 2000.

42. Michallet AS, Nicolini F, Fürst $S$, et al. Outcome and long-term follow-up of alloreactive donor lymphocyte infusions given for relapse after myeloablative allogeneic hematopoietic stem cell transplantations (HSCT). Bone Marrow Transplant; v. 35, n. 6, p. 601-608, 2005. doi:10.1038/ sj.bmt. 1704807

43. Weisser M, Tischer J, Schnittger S, Schoch C, Ledderose G, Kolb HJ. A comparison of donor lymphocyte infusions or imatinib mesylate for patients with chronic myelogenous leukemia who have relapsed after allogeneic stem cell transplantation. Haematologica; v. 91, n. 5, p. 633-666, 2006.

44. Chalandon Y, Passweg JR, Guglielmi C, et al. Early administration of donor lymphocyte infusions upon molecular relapse after allogeneic hematopoietic stem cell transplantation for chronic myeloid leukemia: a study by the Chronic Malignancies Working Party of the EBMT. Haematologica; v. 99, n.9, p. 1492-1498, 2014.doi:10.3324/ haematol.2013.100198

45. Dazzi F, Szydlo RM, Craddock C, et al. Comparison of single-dose and escalating-dose regimens of donor lymphocyte infusion for relapse after allografting for chronic myeloid leukemia. Blood; v. 95, n. 1, p. 67-71, 2000.

46. Simula MP, Marktel S, Fozza C, et al. Response to donor lymphocyte infusions for chronic myeloid leukemia is donnse-dependent: the importance of escalating the cell dose to maximize therapeutic efficacy. Leukemia. v. 21, n. 5, p. 943-948, 2007.

47. Shanavas M, Messner HA, Kamel-Reid S, et al. A comparison of long-term outcomes of donor lymphocyte infusions and tyrosine kinase inhibitors in patients with relapsed CML after allogeneic hematopoietic cell transplantation. Clin Lymphoma Myeloma Leuk; v. 14, n. 1, p.8792, 2014.

48. Zeidner JF, Zahurak M, Rosner GL, Gocke CD, Jones RJ, Smith BD. The evolution of treatment strategies for patients with chronic myeloid leu- 
kemia relapsing after allogeneic bone marrow transplant: can tyrosine kinase inhibitors replace donor lymphocyte infusions?. Leuk Lymphoma. v.56, n.1, p. 128-134, 2015.

49. Shimoni A, Volchek Y, Koren-Michowitz M, et al. Phase $1 / 2$ study of nilotinib prophylaxis after allogeneic stem cell transplantation in patients with advanced chronic myeloid leukemia or Philadelphia chromosome-positive acute lymphoblastic leukemia.

50. Cancer, v. 121, n. 6, p. 863-871, 2015.doi:10.1002/ cncr.29141

51. DeFilipp Z, Langston AA, Chen Z, Zhang C, Arellano ML, El Rassi F, et al. Does Post-Transplant Maintenance Therapy With Tyrosine Kinase Inhibitors Improve Outcomes of Patients With High-Risk Philadelphia Chromosome-Positive Leukemia? Clin Lymphoma Myeloma Leuk; v. 16, n. 8, p. 466-471, 2016.

52. Giebel S, Czyz A, Ottmann O, Baron F, Brissot E, Ciceri $F$ et al. Use of tyrosine kinase inhibitors to prevent relapse after allogeneic hematopoietic stem cell transplantation for patients with Philadelphia chromosome-positive acute lymphoblastic leukemia: A position statement of the Acute Leukemia Working Party of the European Society for Blood and Marrow Transplantation. Cancer; v. 122, n. 19, p. 2441-51, 2016.

53. Carpenter, P.A., D.S. Snyder, M.E. Flowers, J.E. Sanders, T.A. Gooley, P.J.Martin, et al., Prophylactic administration of imatinib after hematopoietic cell transplantation for high-risk Philadelphia chromosome-positive leukemia. Blood; v. 27, n.6, p. 2791-3, 2007.

54. Pfeifer, H., B. Wassmann, W. Bethge, J. Dengler, M. Bornhauser, M. Stadler, et al., Randomized comparison of prophylactic and minimal residual disease triggered imatinib after allogeneic stem cell transplantation for BCR-ABL1 - positive acute lymphoblastic leukemia. Leukemia; v. 27, n.6, p. 1254-62, 2013.

55. Egan DN, Beppu L, Radich JP. Patients with Philadelphia-positive leukemia with $B C R-A B L$ kinase mutations before allogeneic transplantation predominantly relapse with the same mutation. Biol Blood Marrow Transplant; v. 21, n.1, p. 184189, 2015. doi:10.1016/j.bbmt.2014.09.012

56. Cullis JO, Schwarer AP, Hughes TP, et al. Second transplants for patients with chronic myeloid leukaemia in relapse after original transplant with T-depleted donor marrow: feasibility of using busulphan alone for re-conditioning. $\mathrm{BrJ}$ Haematol; v. 80, p. 33-39, 1992.

57. Cervantes F, Dupriez B, Pereira A, et al. New prognostic scoring system for primary myelofibrosis based on a study of the International working group for myelofibrosis research and treatment. Blood; v. 113, n. 13, p. 2895-2901, 2009. doi:10.1182/blood-2008-07-170449

58. Passamonti F, Cervantes F, Vannucchi AM, et al. A dynamic prognostic model to predict survival in primary myelofibrosis: A study by the IWG-MRT (International Working Group for Myeloproliferative Neoplasms Research and Treatment). Blood; v.115, n. 9, p. 1703-1708, 2010. doi:10.1182/blood-2009-09-245837

59. Gangat N, Caramazza D, Vaidya R, et al. DIPSS plus: A refined dynamic international prognostic scoring system for primary myelofibrosis that incorporates prognostic information from karyotype, platelet count, and transfusion status.J Clin Oncol; v. 29, n. 4, p. 392-397, 2011. doi:10.1200/ JCO.2010.32.2446

60. Ali H, Aldoss I, Yang D, et al. MIPSS701 v2.0 predicts long-term survival in myelofibrosis after allogeneic HCT with the Flu/Mel conditioning regimen. Blood Adv; v. 3, n. 1, p. 83-95, 2019.

61. Gagelmann N, Ditschkowski M, Bogdanov R, et al. Comprehensive clinical-molecular transplant scoring system for myelofibrosis undergoing stem cell transplantation. Blood; v. 133, n. 20, p. 2019. doi:10.1182/blood-2018-12-890889

62 Kröger N, Giorgino T, Scott BL, et al. Impact of allogeneic stem cell transplantation on survival of patients less than 65 years of age with primary myelofibrosis. Blood; v. 125, n. 21, p.33473350, 2015. doi:10.1182/blood-2014-10-608315

63. Gowin K, Ballen K, Ahn KW, et al. Survival following allogeneic transplant in patients with myelofibrosis. Blood Adv; v. 4, n. 9, p. 1966- 1973, 2020. doi:10.1182/bloodadvances.2019001084

64. Stewart WA, Pearce R, Kirkland KE, et al. The role of allogeneic SCT in primary myelofibrosis: A British Society for Blood and Marrow Transplantation study. Bone Marrow Transplant; v. 45, n. 11, p. 1587-1593, 2010. doi:10.1038/bmt.2010.14

65. Kröger NM, Deeg JH, Olavarria E, et al. Indication and management of allogeneic stem cell transplantation in primary myelofibrosis: A con- 
sensus process by an EBMT/ELN international working group. Leukemia; v. 29, n. 11, p. 21262133, 2015. doi:10.1038/leu.2015.233

66. Popat U, Mehta RS, Bassett R, Piyanuch Kongtim $P$, et al Optimizing the Conditioning Regimen for Hematopoietic Cell Transplant in Myelofibrosis: Long-Term Results of a Prospective Phase II Clinical Trial. Biol Blood Marrow Transplant; v. 26, 8, p. 1439-1445, 2020.

67. Slot S, Smits K, Van De Donk NWCJ, et al. Effect of conditioning regimens on graft failure in myelofibrosis: A retrospective analysis. Bone Marrow Transplant; v. 50, n.11, p. 2015. doi:10.1038/ bmt.2015.172

68. Kröger N, Holler E, Kobbe G, et al. Allogeneic stem cell transplantation after reduced-intensity conditioning in patients with myelofibrosis: A prospective, multicenter study of the Chronic LeukemiaWorking Party of the European Group for Blood and Marrow Transplantation. Blood; v. 114 , n. 26 , p. $5264-5270,2009$. doi:10.1182/ blood-2009-07-234880

69. Raj K, Eikema DJ, McLornan DP, et al. Family Mismatched Allogeneic Stem Cell Transplantation for Myelofibrosis: Report from the Chronic Malignancies Working Party of European Society for Blood and Marrow Transplantation. Biol Blood Marrow Transplant; v.25, n. 3, p. 522-528 2019. doi:10.1016/j.bbmt.2018.10.017

70. Murata M, Takenaka K, Uchida N, et al. Comparison of Outcomes of Allogeneic Transplantation for Primary Myelofibrosis among Hematopoietic Stem Cell Source Groups. Biol Blood Marrow Transplant; v. 25, n. 8, p. 2019. doi:10.1016/j. bbmt.2019.02.019
71. Bacigalupo A, Soraru M, Dominietto A, et al. Allogeneic hemopoietic SCT for patients with primary myelofibrosis: A predictive transplant score based on transfusion requirement, spleen size and donor type. Bone Marrow Transplant; v.45, n.3, p. 458-463, 2010. doi:10.1038/bmt.2009.188

72. Gupta V, Kosiorek HE, Mead A, et al. Ruxolitinib Therapy Followed by Reduced-Intensity Conditioning for Hematopoietic Cell Transplantation for Myelofibrosis: Myeloproliferative Disorders Research Consortium 114 Study. Biol Blood Marrow Transplant; v.25, n.2, p. 256-264, 2019. doi:10.1016/j.bbmt.2018.09.001

73. Salit RB, Scott BL, Stevens EA, Baker KK, Gooley TA, Deeg HJ. Pre-hematopoietic cell transplant Ruxolitinib in patients with primary and secondary myelofibrosis. Bone Marrow Transplant; v. 55, n.1, p. 70-76, 2020.doi:10.1038/s41409-0190523-3

74. Kröger N, Shahnaz Syed Abd Kadir S, Zabelina $\mathrm{T}$, et al. Peritransplantation ruxolitinib prevents acute graft-versus-host disease in patients with myelofibrosis undergoing allogenic stem cell transplantation. Biol Blood Marrow Transplant; v. 24, n. 10, p. 2152-2156, 2018.

75. Bregante S, Dominietto A, Ghiso A, Raiola AM, et al. Improved Outcome of Alternative Donor Transplantations in Patients with Myelofibrosis: From Unrelated to Haploidentical Family Donors. Biol Blood Marrow Transplant; v. 22, n. 3, p. 324-329, 2016.

76. Raj K, Eikema D-J, Mclornan DP, Olavarria E, et al. Family Mismatched Allogeneic Stem Cell Transplantation for Myelofibrosis: Report from the Chronic Malignancies Working Party of European Society for Blood and Marrow Transplantation. Biol Blood Marrow Transplant; v. 22, n. 3, p. 2019. 